\title{
Intermédialités
}

Histoire et théorie des arts, des lettres et des techniques

Intermediality

History and Theory of the Arts, Literature and Technologies

\section{Knowledge Experiments: Technology and the Library}

\section{Paulina Mickiewicz}

Numéro 18, automne 2011

archiver

archiving

URI : https://id.erudit.org/iderudit/1009076ar

DOI : https://doi.org/10.7202/1009076ar

Aller au sommaire du numéro

\section{Éditeur(s)}

Revue intermédialités (Presses de l’Université de Montréal)

ISSN

1705-8546 (imprimé)

1920-3136 (numérique)

Découvrir la revue

Citer cet article

Mickiewicz, P. (2011). Knowledge Experiments: Technology and the Library.

Intermédialités / Intermediality, (18), 101-119. https://doi.org/10.7202/1009076ar
Résumé de l'article

Qu'est-ce que la bibliothèque du $21^{\mathrm{e}}$ siècle ? Un système nerveux central pour les technologies des nouveaux médias émergents ; un site qui centralise des réseaux et des systèmes de plus en plus décentralisés ; non seulement un emplacement localisable où ces technologies nouvelles sont chez elles, un endroit incarné qui peut les contenir, mais encore un site qui met en scène la rencontre entre citoyens, savoir public et culture. Cet article s'attache à explorer la « technologisation » de la bibliothèque. L'article étudie plus précisément comment ce processus de " technologisation " a transformé notre utilisation et notre compréhension de la bibliothèque en tant qu'espace public et ce que cela peut signifier pour son avenir. L'idée défendue est que la bibliothèque est un médium important en soi et n'a pas été suffisamment explorée dans le contexte et des études en communication et de celles des médias. 


\title{
Knowledge Experiments: Technology and the Library
}

\author{
Paulina Mickiewicz
}

I

n the conclusion to his book The Library at Night, Alberto Manguel seeks

to dispel the pervasive fear that new and emergent technologies have always bred, and continue to breed, about the precarious future of the printed word:

Every new technology has advantages over the previous one, but necessarily lacks some of its predecessors attributes. Familiarity, which no doubt breeds contempt, breeds also comfort; that which is unfamiliar breeds distrust. ${ }^{1}$

These concern not only the form of the book or the obsolescence of the traditional library but also, by extension, the uncertain transformations of the ways in which we read and conduct research, whose invaluable quality some critics have claimed are being eroded by the emergence of the World Wide Web. Manguel writes that "the new sense of infinity created by the Web has not diminished the old sense of infinity inspired by the ancient libraries; it has merely lent it a sort of tangible intangibility." 2 The claim can be made that the library is in fact not obsolete but rather has transformed itself, and this, to the surprise of many scholars, not in the ways that had been predicted in the 1980 s and 9os-this is due, in particular, to the development and proliferation of the personal computer, as well as the development of "other means for storage and transmission of information and knowledge." "Many scholars throughout the 1980s and gos were preoccupied with the idea that the principal way in which the library would adapt in an information society would be to transform from a material entity into an immaterial one. In Civic Space/Cyberspace, Kathleen Molz Redmond and Phyllis Dain cite William J. Mitchell as predicting "that the façade of the library

1. Alberto Manguel, The Library at Night, Toronto, A.A. Knopf, 2006, p. 321.

2. Ibid., p. 322.

3. Kenneth E. Dowlin, The Electronic Library: The Promise and the Process, New York, Neal-Schuman, 1984, p. v. 
'is not to be constructed of stone and located on a street in Bloomsbury, but of pixels on thousands of screens scattered throughout the world...there is nothing left to put a grand facade on.' Cyberspace would replace civic space-or would it?" Cyberspace has not replaced civic space. Rather, when addressing the question of the library today, it would be more accurate to say that cyberspace has come to be contained within civic space.

In what follows, I contend that the library has in fact become a central nervous system for new and emergent media technologies - a site that centralizes increasingly decentralized networks and systems - and a localizable place in which new and emergent media technologies have not only found a home-an embodied place where they can be contained-but also a broader site in which the encounter between citizens, public knowledge and culture is staged, thus equally commingling past, posterity and the present. The modern library is the library that "contains" cyberspace, or at least public access to it.

This article seeks to explore the "technologization" of the library. More specifically, it will examine how this process of "technologization" has transformed the ways in which we use and understand the library as a public space, as well as what this may mean for the future of libraries. I wish to propose that the idea of the library as an important medium in itself has been overlooked in the broader context of communication and media studies. The following article will pursue these questions in two parts. In the first part, I will examine how libraries have become, to borrow a term from Andrew Barry, "technological zones" as much as they have remained civic spaces. For Barry, "[zones] are not fixed structures within which action takes place. Zones are always in process. They demand regeneration, adjustment and reconfiguration: frequent maintenance work." It is this idea of the regeneration of the library that I wish to explore, in order to establish how, through the strategic deployment of technology and design, libraries have become new, almost experimental sites of knowledge. The second part of this article will consider the technologizing effects of the Grande Bibliothèque du Québec in Montréal (GB). The GB, and particularly its digitization initiatives, is an interesting instance in which the undetermined future of what a library can be is played out. Because of its mix of both national and public mandates, the GB evokes competing narratives around what forms of citizen-

4. Kathleen Molz Redmond and Phyllis Dain, Civic Space/Cyberspace: The American Public Library in the Information Age, Cambridge (Mass.), MIT Press, 2001, p 10.

5. Andrew Barry, Political Machines: Governing a Technological Society, London, New York, Athlone Press, 2001, p. 40. 
ship-technological, national, civic - the library, as a mediating technology, will, or should, foster. The case of the GB speaks to a broader trend currently taking place with regard to libraries in the digital age; hence the importance of treating it within this larger context of the changing relationship between libraries and technology, and of investigating how this relationship has transformed perceptions of what contemporary civic institutions such as libraries can be, and what mediated shapes they can take.

\section{TECHNOLOGY AND DESIGN}

To claim that the "traditional library" has not in fact been replaced by the socalled digital library is not to say that its façade has not changed, that its shape has not been deeply modified. The library is not obsolete precisely because it has transformed and re-adapted itself to its environment over the centuries, and this environment has become increasingly technological. These technologies, although they have not superseded the library, have nonetheless had a tremendous impact on modern library design. The "traditional library" in North America, ${ }^{6}$ that ideal form propagated by American industrialist and philanthrop-

6. I use the term "North America" in relation to Andrew Carnegie a bit loosely here. It is well known that Carnegie established the public library system as we have come to know it today throughout Canada and the United States (in fact, Carnegie financed more than 2500 public libraries around the world, 150 of which are in Canada). However, it should be noted that Québec has a specific historical lineage when it comes to public libraries, and it is one that does not include Andrew Carnegie. This is not to say that Québec was overlooked by Carnegie; on the contrary, Carnegie donated $\$ 150$ ooo to the creation of a free public library in Montréal in 1901. Nonetheless, Montréal, and Québec as a whole, remained in deep debate on the merits of a public library that would be independent; in other words, not in the hands of the clergy. At the time, the clergy in Québec had a strong hold on most cultural institutions, and envisioned a specific type of citizen, morally grounded in Christian values that needed to be secured against threats posed by exposure to certain secular texts. Therefore, although Québec eventually saw the creation of a public library, it did not see the construction of a Carnegie building. Carnegie's generous donation in 1901 was in fact refused; the argument was that Montréal did not truly need a municipal public library, as the public could be better served if resources were allocated to the already existing parish libraries. In short, the "traditional library" that I discuss in this section as one that mirror's Carnegie's architectural preferences does not necessarily pertain to the case of Québec. However, it can be argued that Québec's traditional or first public libraries, at least those that can be found in Montréal, still mirror the "traditional" prototype described above. See: Denis Goulet, Bibliothèque et archives nationales du Québec. Un siècle d'histoire, Québec, BANQ and Fides, 2009, p. 12. 
ist Andrew Carnegie, has had to adapt and change in interaction with the ever increasing demand for digitized information, the new forms of temporal access enabled by the Internet, as well as the broader transformations taking place around media protocols in human practices of communication. In fact, technological sophistication has become almost synonymous with what we consider to be a successful modern library. Andrew Barry highlights this point when he argues that:

This is an era obsessed by a series of interconnected technological problems: with the maintenance of technological competitiveness and the improvement of research productivity; with the need to patent and protect intellectual property; with the dangers posed by the unintended consequences of technological development; with the public understanding of science; with the risks and prospects for e-commerce and electronic democracy; and with the need for life-long learning in the face of rapid technical change. ${ }^{7}$

The last point that Barry makes directly implicates the library as one of the institutions called upon to provide this level of technological sophistication. In short, without these contemporary demands-the result of technological innovations and societal adaptation in flux-Carnegie's library might very well have remained a "traditional" mix of stone buildings, paper-bound books, and a sitespecific democratic imperative of access.

There is a distinction to be made here between what qualifies as the "traditional" library and what as the "modern," at least in the ways these terms will be used in this article. It could be argued that the idea of the modern library dates as far back as 1523, when the merchant Medici family commissioned the construction of Michelangelo's Laurentian Library in Florence. The library was built primarily in order to make the political statement that the Medici family had moved into the upper echelons of society and were now members of the Italian intelligentsia and religious society rather than mere merchants; library architecture during this period reflected the relationship that books held to power (just as contemporary library design reflects the relationship between power and digital networks).

The Laurentian Library, designed and built by Michelangelo, is renowned for its architecture, but it is also significant because Michelangelo's design and innovative use of space were revolutionary for the time. According to James Murdock, this particular library would serve as the model for future libraries, which would be characterized by rows of desks that would "dominate a nave- 
like reading room." ${ }^{8}$ Libraries continued to take on this "temple of knowledge"like form throughout the Enlightenment, even when the political identity of the library had begun to move away from its association to power to adopt its more democratic characteristics. In the more recent past, remnants of this prototype can be found in the familiar image we have come to associate with libraries: a Beaux Arts building façade within which "[books] line the walls of these buildings' vast reading rooms, while tables and carrels occupy most of the floor space." In North America, this is the free, public and democratic space we have come to associate with Andrew Carnegie; a quiet space that contains books, and not much else. This is the image of the "traditional" library in relation to which the imagination and materiality of the contemporary library might be cast into relief. The $21^{\text {st }}$ century library can be seen as an emerging medium that seeks to not only preserve and disseminate collective memory and culture, but also to provide access to spaces and networks of knowledge, culture and interaction, which together renovate the library's traditional role as a democratic institution.

Over the last fifty years or so, there has been a significant trend towards redesigning the traditional Carnegie library. Shannon Mattern, author of Designing With Communities: The New Downtown Library, writes that:

By the 196os, "there was a discernible trend toward replacing old Carnegie librarie" with "modernistic, inviting, and often architecturally distinguished" buildings. Among these new buildings, no single architectural style dominated, as the Beaux Arts had done for decades before, thanks to the influence of Carnegie and his favoured architects. ${ }^{10}$

This trend towards new modern library design, although particular to North America as made visible through the re-imagination of the Carnegie library, can be seen all over the world, particularly in the 1990s and throughout the 2000s, a period which has seen the emergence of a number of architecturally innovative new libraries. As a result, it could be argued that there is more going on with new library design than a mere re-imagination of the Carnegie library; that we are, in fact, seeing a significant transformation of the identity of the library in the face of digitization. What kind of publics does it serve? What kind of space should it be? What functions is it meant to perform?

8. James Murdock, "Beauty and the Book: Libraries in the Digital Age Raise Questions About the Place of Books," Architectural Record, March 2011, p. 56.

9. Ibid.

10. Shannon Mattern, The New Downtown Library: Designing With Communities, Minneapolis, University of Minnesota Press, 2007, p. 4. 
These are the kinds of questions that renowned Dutch architect Rem Koolhaas posed while designing the Seattle Public Library, which opened in May of 2004. Mattern cites Koolhaas as arguing that many new libraries, particularly "those built before the mid-gos, 'don't reinvent or even modernize the traditional institution; they merely package it in a new way.' Koolhaas wanted to go beyond packaging;... [he] attempted, through his design, to 'reinvent the idea of the library,' both functionally and architecturally." 11 As Mattern goes on to explain, Koolhaas recognized that the reinvention of the library went beyond form; rather, its very purpose needed to be re-imagined "because, as he put it, the 'legitimacy' of the library is under question." 12 What the Seattle Public Library succeeded in doing, as did many other libraries of its kind, such as the Vancouver Public Library (1996), the Bibliotheca Alexandrina (2002), and the GB (2005), to name a few, was to make a clean break from both what the Carnegie library looked like and what it stood for. The libraries of the mid to late 1990 s and early 2000 s began to alter the discussion about what a library is and what it should be. As Mattern writes with regards to Koolhaas's design:

This approach to design means rebuilding the operative ideology of the library as one rebuilds the physical library itself. In this case it seems that the antitype - that is, design not relying on precedent but instead based on questions of the very nature and function of the library - is Koolhaas's signature design style. ${ }^{13}$

However, even as recently as the last two or three years, these ideological debates surrounding the purpose of the $21^{\text {st }}$ century library have shifted dramatically as new library designs have begun to reflect discourses that surround technological innovation. As a concrete example, very recently built public libraries have begun to re-imagine or experiment with the idea of a library that is not without walls (as was feared with the increasing impact of digitization), but a library whose walls contain either a limited number of books or no books at all. More accurately, we can say that the newest kind of library is one that contains books, but in new formats. The principal architect from ikon.5 architects, Joseph Tattoni, whose firm has undertaken the design and architecture of several large-scale libraries in the United States, points out that twenty years ago library employees were very resistant to books being moved out of the library. In the last ten years or so, however, this has changed in that there are so many more types of objects that are desired within the space of the library.
11. Ibid., p. 70.
12. Ibid.
13. Ibid., p. 71. 
The issue today is less about the diminishment of books; instead, a conversation is taking place about creating access to other technologies that open up new sources of information. ${ }^{14}$ Consequently, the newest library models not only question where books fit in the digital age, but they also represent the idea that the answer to what the future library will be is unknown. The very idea of the unknown is what defines the library of the digital age and is reflected within its very structure. The newest libraries are built for change. They are as much physically, as they are philosophically, adaptable and flexible to their transformative environments-two attitudes which they are both expected and required to adopt. In other words, the ideological debates surrounding the identity of the modern library have shifted from asking how libraries should reinvent themselves in order to keep up with the times and stave off obsolescence, to suggesting that libraries must be designed to be open to an undetermined future that hinges on emergent technologies whose forms and attendant practices cannot be easily predicted.

When discussions began addressing the construction of the GB, one of the primary goals was to convince taxpayers that building a downtown library was a worthwhile endeavour. This was not unique to Montréal; most libraries being built at the time faced the same issues. As Mattern observes:

One of the first steps in most library design processes is convincing the taxpaying public that it needs a new downtown library building [...]. Despite the fact that most people, whether library patrons or not, are generally supportive of, or at least benevolently ambivalent toward, public libraries, library construction campaigns are occasionally a tough sell [they are] just one of many institutions competing for the same public and private funding. ${ }^{15}$

This was very much the case for the GB. The question that was asked repeatedly was why a building was needed at all? This question was posed to Lise Bissonnette, former Chair and Chief Executive Officer of the GB, and one of the driving forces behind the project. The exact question was why, with the explosion of the internet, was it so important to have a building as a means of promoting culture when the promotion of culture could be achieved in other, newer, presumably more immaterial and innovative ways? Bissonnette's response was one that grew very familiar in the mid-1990s and late 2000s; it aimed to convince citizens that a library with walls was even more necessary in the digital age than it had ever been before:

14. Joseph Tattoni, phone interview on July 14, 2011.

15. Mattern, 2007, p. 9-10. 
Well you know it's a sense of place, I mean the libraries today are becoming, and fast, the center of cities and it's fascinating because they're not traditional libraries anymore as you see when you come in a place like this [the GB]. They're not traditional libraries anymore, they're not a place where people come, take a book and just go out. They're a place where people can stay for a few hours, discover, come to a conference, everything is free by the way here, and we don't accept even when people ask about an entrance fee, and everything is free, there are exhibitions, they can meet with librarians, we'll help them with their personal research. This is a very different place, it's a community place, and even in small villages today it's fast becoming the library, when they build one or when they enlarge one, it's fast becoming the center of the place. It's the new institution for the $2 \mathrm{r}^{\text {st }}$ century, as I say, inside a city. ${ }^{16}$

This is how the first building prototypes of the $21^{\text {st }}$ century library were consistenly being sold. The library's purpose was no longer only to preserve and disseminate culture and memory, and librarians were no longer just archivistguardians of a library's documentary holdings. The library was to become a free space in which communities could gather, and librarians were to become "part reference specialist[s], part social worker[s], and part community organizer[s]." According to Mattern:

The modern library has always been something of a community center-a place where people can gather to learn, whether in a story hour or a craft workshop, in the presence of others. Many observers contend that this role, often referred to as an 'information commons,' must now take center stage. ${ }^{18}$

And it has taken center stage. So much so that the challenge is no longer to convince taxpayers to support a new library project in their cities; the challenge now is to further rethink the library's potential in the face of new and emergent media technologies. The year 2009, in particular, saw the opening of a staggering number of new libraries all over the world, and these libraries-although modeled on the earlier, mid-gos modern libraries-differed in their approaches to what libraries of the future are and what they should be. These new libraries are knowledge experiments in and of themselves.

The Musashino Art University Museum \& Library in Tokyo offers a fascinating example of future potentiality built into the structure of the institution itself.

16. My transcription of an interview with Lise Bissonnette conducted by Hedwidge Asselin and Jim Cullen at the Bibliothèque et Archives nationales du Québec on May 22, 2007. The podcast of the interview is available at www.banq.qc.ca/ressources_en_ ligne/baladodiffusion/index.html?language_id=1(last access January 6, 2012).

17. Murdock, 2011, p. 56.

18. Ibid. 
Originally built in 1962, the Musashino Art University decided to turn its original gallery-library into a museum and build a new library immediately next to it. The result is an incredibly impressive building, described as "a single, spiral-shaped bookshelf encased in a glass box." 19 What is unique about this library is that the bookshelves - which extend from floor to ceiling and make up the entire building in a continuous maze-like formation-are not entirely filled with books; in fact most of the shelves, although they do contain some books, remain empty. A first interpretation is that the architect, Sou Fujimoto, was commenting on the identity of the $21^{\text {st }}$ century library. The library in the digital age is one that is free of books and instead houses books in digital formats and incorporates other new technologies (which are almost invisible when one looks at certain images of the Musashino library). In this sense, Fujimoto's design might echo what Lisa Gitelman perceived to be "amazingly prescient" 20 with regard to what J.C.R Licklider predicted the future library would look like when his study Libraries of the Future was published in 1965. Gitelman writes:

The future Licklider takes as his point of orientation the year 2000 , and the libraries he proposes are what he calls 'procognitive systems' [...] Licklider arrives at a wishful future in which researchers sit at consoles or terminals, typing on keyboards and looking at screens, connecting to and interacting with digital systems to query, search and retrieve information. ${ }^{21}$

Licklider's future library has, by 2009, possibly come and gone. Although computers are still given a place within new library designs, because they have radically diminished in sizes and because many library patrons have their own computing devices, computers have ironically become increasingly invisible within new libraries. However, Fujimoto's intention regarding the Musashino Art University Library's empty bookshelves was not a comment on the potential ephemeral quality of books; in fact, the library was built to celebrate books. Fujimoto originally visualized the library with its bookshelves completely filled with books, but is quoted in Architectural Record as saying " After completion, I found that emptiness is better [...] If you fill up all the shelves, it is just a bookcase. But if you leave it part empty it is full of potential." 22 Interestingly enough,

19. Naomi R. Pollock, "Musashino Art University Museum \& Library, Tokyo, Sou Fujimoto," Architectural Record, March 2011, p. 61.

20. Lisa Gitelman, Always Already New: Media, History, and the Data of Culture, Cambridge (Mass.), MIT Press, 2008, p. 100.

21. Ibid., p. 99-100.

22. Pollock, 2011, p. 67. 
the mostly empty bookshelves were a somewhat unintended consequence of the architectural design. As earthquakes are quite common in Japan, special modifications would have been necessary to allow books to be stacked on shelves over six feet high, not to mention the problem of accessing books placed on higher shelves.

Another example of library experimentation is the newly built Fisher-Watkins Library in Ashburnham, Massachusetts. This library, while not the most innovative in design, has been the most technologically pioneering in its replacement of 20000 printed books with Kindles. The library's mandate, with the heading "A Library Transformed," reads as follows:

In 2009, The Fisher-Watkins Library underwent a digital transformation. The Academy replaced the majority of the library's 20000 printed books with electronic sources as a natural and integral outgrowth of the school's strategic commitment to becoming the national leader in $21^{\text {st }}$-century secondary education, and to providing students with the necessary tools to become lifelong learners in a socially-and globally-connected world. We wanted to create a library that reflected the reality of how students do research and fostered what they do-one that went beyond the stacks and embraced the digital future. ${ }^{23}$

The Fisher-Watkins Library makes visible the fact that a technological shift exists alongside a closely-related discursive shift: here, the perceived facts of emerging technology and emerging narratives concerning the library's purpose and future become mutually reinforcing. In his book Making Digital Cultures: Access, Interactivity, and Authenticity, Martin Hand argues:

[Narratives] of digitization in the library shifts learning from "instruction" to "empowerment," entailing an institutional move from custodialism to interfacing, and a promotion of citizen engaged in indefinite learning. In this sense, the Web (as the latest information machine) has become a powerful set of cultural discourses about the traditional purposes, functions, and effects of public libraries in contemporary information cultures. ${ }^{24}$

For Hand, under the auspices of new and emergent media technologies, the discourse on libraries shifts from a modern pre-occupation with collections, pedagogy, and legitimation, towards a postmodern emphasis on interfacing, empowerment, democratization, and communitarianism. ${ }^{25}$ What I wish to

23. "A Library Transformed," www.cushing.org/library (last access January 6, 2012).

24. Martin Hand, Making Digital Cultures: Access, Interactivity, and Authenticity, Hampshire, Ashgate Publishing, 2008, p. 10.

25. Ibid., p. 83. 
emphasize here is that this shift is not only discursive but, given the two previous examples, is materialized within libraries in tangible ways. The shift is played out in the ways libraries are designed and built (as we have seen here), in the ways librarians's roles are changing, and in the ways patrons are using libraries.

To return to Barry, libraries have become "technological zones;" not simply because they contain technological devices, but because they have become "discontinuous spaces of circulation and regulation." ${ }^{26}$ They are discontinuous because they exceed their own boundaries; they are connected through permissions, and codes and various other access points, to both other libraries and other sources of knowledge and information. Libraries are also "technological zones" because they require a certain expertise that was previously not required. Libraries as sites need to be adaptable, but so do the humans that frequent them.

As Barry argues:

As doctors, auditors, and computer users well know it is never possible to assume that the same technical practice will work in another place in exactly the same way. For however apparently standardized a device is, or is supposed to be, there may also be a need to make adjustments to its design and use [...] In the context of an analysis of technological zones, an expert should not just be thought of as somebody who knows how to use a complicated piece of equipment or perform a difficult task, but rather somebody who is able to make adjustments to this equipment, and to themselves, which take due recognition of the complexity of circumstance. ${ }^{27}$

\section{TECHNOLOGIZING THE GRANDE BIBLIOTHÈQUE}

The idea of the library as a civic space is not a novel one. Libraries have for centuries (at least in Western liberal democracies) been considered spaces in which the potential for civic participation was possible. Libraries have been institutions in which democratic access to knowledge and information would lead to a more informed, knowledgeable and, as a result, engaged citizen, capable of participating and governing herself within a democratic public sphere. The public library is an example of an institution in which Foucault's idea of governmentality is played out. It is an institution that recognizes an individual's "capacity for action," ${ }^{28}$ and encourages it in a way that might produce the desired outcome of civic engagement. It could be argued that this desired form of civic engage-

26. Barry, 2001, p. 41.

27. Ibid., p. 40.

28. Nikolas Rose, Powers of Freedom: Reframing Political Thought, Cambridge and New York, Cambridge University Press, 1999, p. 4. 
ment is both enabled by technology - "[i]nteractive technology is expected to produce active citizens" 29 - and is technological in that "the individual citizen is increasingly expected, and increasingly expects, to make his or her own judgments about scientific and technological matters," 30 judgments that are enabled through access to information.

As was seen in the previous section, libraries have gone from being cultural institutions charged with the preservation of books, cultural heritage and memory in general, to being primarily conditioning media spaces in which technologies are not only stored, but can be accessed freely. Moreover, they have become spaces to which people go in order to engage with the technologies that are on offer, both structurally and cognitively. Emerging media technologies have brought with them a prominent normative vocabulary that centers on notions of access, a normative value that has also at least partially defined the public library's self-image throughout its history. Hand writes that "[the] term 'access' has become pervasive in popular and academic commentary, highlighting inequities and privileges of one kind or another, moral imperatives to eradicate exclusion in favour of inclusion in all areas of societal life, a generalized shift from 'ownership to access' in a new 'experience economy." 31 Indeed, access has become the dominant narrative of digital culture ${ }^{32}$ and, as a result, one of the dominant narratives surrounding these new iterations of the public library. What is more, access has become nearly synonymous with the primary mandate of public libraries to disseminate and promote knowledge, as well as a particular cultural heritage; tasks which can only be accomplished if users have access to the knowledge being promoted and disseminated. New and emergent media technologies that promise enhanced public access to information and knowledge are thus difficult to resist, even for the most bookish of libraries.

In April of 2005, the GB opened in Montréal; it was a library project of unprecedented scale in the city. What makes the story of the GB so unique and significant is that the project's primary goal was to bring the collections of two very different types of libraries into one unifying space. It sought to merge the collections of the Bibliothèque nationale du Québec (BNQ) and the Bibliothèque centrale de Montréal (BCM), a merger that would eventually marry the national, the public, and the civic dimensions of what a library could be. The Grande

29. Barry, 2001, p. 127.

30. Ibid., p. 127-128.

31. Hand, 2008, p. 75.

32. Ibid. 
Bibliothèque project unfolded during a significant moment in the cultural history of Québec, in which contemporary technological changes were-and, as we have seen, are still_exerting transformative pressures on traditional models of the library. These same technologies have come to play an increasingly important role in the broader formation, circulation, and reproduction of cultural practices and identities. One of the main reasons for creating the GB was to offer Montréal citizens a public library that could not only host and manage emergent media technologies, but would provide free and equal access to these new media. In addition to being a highly digitized and networked facility, the GB is also a site that offers the most advanced methods of storage, search and retrieval of a multiplicity of collections, be they referential, digital or archival. It thus presents a significant attempt to combine the allegedly democratic character of networks with the traditionally civic priorities of public libraries.

With the growing impact of new and emergent media, and the increasing expectation of users to be able to engage with and have access to these technologies, constructing the GB went beyond issues of space constraints and documentary holdings and offerings. Indeed, a technological imperative rapidly took precedence over competing priorities and exerted enormous influence on the design aspects of the building itself. The normative imperative of access arguably accounts for the GB's \$17 million CAD construction investment in information technology infrastructure. The GB has more than one hundred multimedia stations available to its patrons. These workstations are located on all levels throughout the library, and allow users to access the Internet, many electronic resources, including databases, the Iris catalogue, and various applications. The library also has a music and film section, and a viewing room and viewing stations for on-site viewing of part of the library's film collection. The section also offers listening stations facilitating the on-site consultation of sound works and music shows. In addition to a language laboratory, there are also music rooms. These are small studios where interested patrons can perform, manipulate or create sound works in electronic formats. Finally, the library contains what it calls the Logithèque, which consists of 12 multimedia stations with software applications and educational software that teaches patrons how to use this software. As such, in addition to being a significant architectural statement in the city of Montréal, the GB is also a highly mediatized and technologized site. The GB's digital character, and its technical imperatives, have conditioned its structural design in an important way; the bit, in the case of the GB, preceded the brick. In fact, the library's virtual collection, one of the most advanced in the world, was launched before the library itself was opened. The design of the library was as much about preparing 
the structure for necessary IT services as it was about the look and feel of the library space.

The development of a virtual space mediated through various forms of information technologies has made it such that the real space of the library is all the more necessary - both as a form of containment and as a site in which an increasingly fragmented population might find some societal cohesion. In addition, cyberspace and mediating technologies have transformed the way we think about informed and engaged citizens. For Andrew Barry, we have become increasingly preoccupied with what he has termed "technological citizenship." He writes:

The citizen of a technological society expects and is expected to be informed and updated. She should be knowledgeable about the risks of smoking and the side-effects of drugs, be ready to learn about the latest advances and advantages of new information technologies, the strengths and weaknesses of "medical" and "natural" approaches to childbirth, the possible consequences of eating fats, sugars or GM foods, and the advantages and disadvantages of different forms of exercise and diet. She has to be knowledgeable about the multiple intersections and connections between her body and pollutants, drugs and technical devices, and the dangers and possibilities such connections may open up. Her health and her environment are matters of choice. Technological innovation forms new artefacts. The government of a technological society implies the formation of new human capacities and attributes. ${ }^{33}$

There are multiple layers to the technological citizen, the first being that with our current technological advancements, it has never been easier to be more informed; consequently, we have a moral obligation as citizens to inform ourselves as well as to stay informed. We also, however, need to have the capacity to manipulate the technology which will give us access to information; a skill which has become a staple in the training that educational institutions such as schools, universities, and libraries. Libraries have an added responsibility; they are expected to offer this training to all citizens for free.

In the case of the GB, a tension exists between the emphasis placed on the importance of technology in forming a new type of engaged, empowered, and informed "technological citizen," and the library's mandate "to provide democratic access to the published heritage constituted by its collections, to culture and to universal knowledge." ${ }^{34}$ A similar tension can be traced between the traditional responsibilities of the library centered on collection and pedagogy, and

33. Barry, 2001, p. 4.

34. The Bibliothèque et Archives nationales du Québec mission statement can be found at www.banq.qc.ca/a_propos_banq/mission_lois_reglements/mission/ (last access January 6, 2012). 
its modern preoccupations, centered on interfacing and democratization. Lise Bissonnette, in attempting to define what kind of institution the GB is aiming to be, highlights this tension in an interview from May of 2007 :

[The] library was first and foremost a cultural proposal, and somebody told me well you can talk about culture but we're mostly about information, and I was struck because I thought this was sort of a cliché that I was saying this was a cultural proposal, and we have to fight that all the time. I must tell you that in libraries this is really becoming a problem because of the technologies and because of this idea that information is first and foremost [...] there's been a trend in the past twenty years to think that information is more important than anything else, that if you have information you can sail through life and that if you have information you have power, it's not true certainly, but they have succeeded in putting that in the head of young people. So we have again to resist that $[. .$.$] and I think that culture has a tendency to go out of$ libraries as it went out of universities and colleges, so we must resist that. That's why this building is like it is [...] We've been infatuated with all this information technology, yes, but what we're doing with IT here is really a cultural proposal, also because we're digitizing our heritage at a fast pace and it's very interesting. ${ }^{35}$

Bissonnette, although she admits that technology is a necessary and expected component of the $21^{\text {st }}$ century library, argues that it has simultaneously taken precedence over cultural and civic responsibilities that the institution should be focused on promoting. For Bissonnette, however, this tension is interestingly resolved in the GB. First, it houses a general reference library as well as Québec's national heritage collection, and such cultural spaces as a café, a lecture theatre and an art gallery and, second, it has taken advantage of technology to fulfill its mandate in forming a "technological citizen" as well as a national one. The library building, according to Bissonnette, is crucial in fulfilling the civic role of the library and, at the same time, necessary for harbouring the technologies that enable access to Québec's national patrimony through digitization. For the GB, "l'accès au patrimoine culturel constitue un droit pour tous les citoyens." 36 The $\mathrm{GB}$, and particularly its digitization initiatives, is an interesting instance in which the undetermined future of what a library can be is displayed. Because of its mix of both national and public characteristics, the GB evokes competing narratives around what forms of citizenship - technological, national, civic-the library as a mediating technology will or should foster.

35. Bissonnette, 2007.

36. "Appel à la numérisation du patrimoine culturel québécois," BAnQ, www.banq. qc.ca/appel_numerisation/index.html?language_id=3 (last access January 6, 2012). 
On December 6, 2010, the GB, along with the Société des musées québécois (SMQ) and 18 other organizations, launched an appeal for the digitization of Québec's cultural heritage. The press release reads as follows: "Faced with the need to guarantee that Québec's cultural heritage be preserved, and to ensure that it is available on the Web, the multidisciplinary committee of the Réseau québécois de numérisation patrimoniale (RQNP) is inviting citizens and professionals involved in information, education and culture to support its actions by signing the Appeal for the digitization of Québec's cultural heritage." ${ }^{37}$ The appeal responded to an initiative, launched by the GB in 2006, which sought to investigate the state of digitization of Québec's cultural heritage and whose results were published in a final survey in 2009. The survey reported that a mere 6 percent of Québec's heritage collections had been digitized; an unacceptable number given that the GB as a national institution seeks to offer the same kinds of democratic access to Québec's national patrimony to all citizens of Québec, as it offers on site to citizens living in its direct vicinity. The report also highlighted that 74 percent of survey participants declared that they were "extremely interested" in participating in a networked digitization project of Québec's national patrimony; however, 79 percent of interested participants admitted to not having adequate human or financial resources at their disposal to properly realize such a vast digitization goal. In response to these findings, in a speech delivered on November 13, 2009, Chair and Chief Executive Officer of the Grande Bibliothèque, Guy Berthiaume, asked for collective engagement, not only from cultural institutions in Québec, but also from the general public, in support of a national digitization project. ${ }^{38}$ Only through collective engagement would it be possible to respond to the technological expectations of the moment, and be somewhat competitively positioned with regard to the commercial initiatives of corporate enterprises such as Google. In the press release from 2010, Berthiaume is quoted as saying:

As has rarely happened in the past, we find that our professions are at the heart of what is truly a societal issue. With the abundance of possibilities that new technolo-

37. "BAnQ, the SMQ and 18 organizations launch an appeal for the digitization of Québec's cultural heritage," BAnQ, www.banq.qc.ca/a_propos_banq/salle_de_presse/communiques_de_presse/2010/com_2010_12_06.html?language_id=1 (last access January 6, 2012).

38. "Discours et allocutions," BAnQ, www.banq.qc.ca/a_propos_banq/salle_de_ presse/discours_allocutions/2009/numerisation_patrimoniale.html?language_id=3 (last access January 6, 2012). 
gies are opening to us, our responsibility is fundamentally engaged in the survival and the spread of our heritage. ${ }^{39}$

As much as new and emergent technologies are facilitating the preservation and the dissemination of cultural heritage and broader forms of knowledge, Berthiaume makes an important point when he brings up the notion of responsibility. In calling on the support of the citizens of Québec, as well as other cultural institutions in the province, one could argue that a claim is being made in support of the idea that the responsibility of preserving culture and making it more accessible is the responsibility of society as a whole. Libraries, museums, and other cultural institutions can be mediators of various decision making processes, but these decisions should not only be made public, but should come from the constituent publics themselves.

What I wish to emphasize here is that there exists a tension between technology being both at the forefront of new library design and an imperative for civic institutions to educate technological citizens, as is seen with the example of the $\mathrm{GB}$, and a resistance to technological agency. Both Berthiaume and Bissonnette echo a concern over the increasing expectation that technologies will correct societal failures. For them, technology alone cannot account for the preservation and dissemination of Québec's cultural heritage. Public engagement and an interest in maintaining cultural heritage are as necessary as the mediating technologies that opened up the possibilities for these types of projects to exist. People are part of the library's "resources," and not in an exploitative way; rather, this constitutes a materialization of our participation in the public spaces of technological citizenship. Consequently, it is both the ideological and material invisibility and visibility of technologies that highlight the future uncertainties built into the very structures of the $21^{\text {st }}$ century library.

\section{LIBRARY MEDIATIONS}

What this article has intentionally left in the background is an irony that is in fact at the concealed core of the modern technological library. Although the modern library is a highly and increasingly technologized space, it is also a space that tends to render these very same technologies invisible. Technologization, as I have hopefully made clear, is a contingent process made up of multiple actors, both material and immaterial, from architects and their designs to library offi-

39. "BAnQ, the SMQ and 18 organizations launch an appeal for the digitization of Québec's cultural heritage," 2010. 
cials and their calls for digitization. Just as the regenerative agency that Barry's “technological zones" relies on is strategic, those selfsame strategies are so often concealed behind both grand architectural facades and complex technological infrastructures. As Lisa Gitelman argues:

[The] success of all media depends at some level on inattention or 'blindness' to the media technologies themselves (and all of their supporting protocols) in favor of attention to the phenomena, 'the content,' that they represent for users' edification or enjoyment. ${ }^{40}$

What is so interesting about what I call "experimental" library design is an inherent contradiction; not only has the contemporary library demonstrated a new commitment to the technological, most clearly manifested through archi$\mathbf{1} \mathbf{8}$ tectural grandiosity, but it has also, possibly unintentionally, generated an inattention or blindness to technology. The invisibility of media technologies has been built into the very structures of the buildings themselves. In the GB, for example, all the wiring necessary for computer networks and other electrical devices is hidden within the floors, and connects to computers and the like by way of the furniture. The desks are designed in such a way that wiring is camouflaged within the foot of the table and connected to the wiring in the floors. Patrons are meant and even encouraged-by librarians, architects, public officials, and some measure of public consultation - to forget the media technologies within the library. Libraries are focused on making their patrons feel "comfortable," and although technologies have become so pervasive in today's world there still exists an element of distrust, to return to Manguel, when it comes to that which we cannot entirely grasp.

As this article has attempted to demonstrate, this discomfort may lie in the fact that we seem to still hold onto the simplicity of the traditional library even though we expect the complexities of the newly technologizing library. The tensions put forth in this article, highlighting the somewhat contradictory nature of the contemporary library as combining new technological imperatives with the older idea of the library as a civic institution, are a testament to some of these discomforts. As Gitelman argues, we might tend to naturalize or essentialize technology in the library; as seen with the GB, however, there exists a conscious and necessary resistance to this so-called essentialization, wich allows the library to retain its more traditional cultural and civic commitments. Rather than becoming spaces that merely celebrate the technological, libraries have adapted to and incorporated the environment of technological agency by becoming contain- 
ers in which technologies can be accessed, stored and navigated. In her article "Container Technologies," Zoe Sofia writes:

[The] processes of containment and supply, and the utensils, apparatus, and utilities that help extract, store, and distribute resources from the standing-reserve, are not relics of pre-modernity but continue to define a fundamental aspect of what technology is in the late modern epoch: it is about supply, securing access, rapidly making resources available for distribution and consumption. ${ }^{41}$

In this vein, today's library can be seen as more than just a cultural institution; it is not only a storage facility for a multitude of technologies, but also a mediating technology in itself. It contains both technological objects and an important civic-technological imperative; to borrow from Sofia, it could be considered "a technology of re-sourcing: it can be filled from a source, then itself becomes a source of what it has kept and preserved." ${ }^{42}$

41. Zoe Sofia, "Container technologies," Hypatia, vol. 15, nº 2, Spring 2000, p. 196. 42. Ibid., p. 192. 